\title{
WACANA BHINEKA TUNGGAL IKA DALAM BUKU TEKS SEJARAH
}

\author{
Indah Wahyu Puji Utami \& Aditya Nugroho Widiadi \\ Jurusan Sejarah, Fakultas Ilmu Sosial, Universitas Negeri Malang \\ Indahwahyu.p.u@um.ac.id
}

\begin{abstract}
Textbook is one of learning sources used in history learning in school. History learning has function to preserve collective memories and necessary values, such as Bhineka Tunggal Ika. This research aims to reveal depiction and representation of Bhineka Tunggal Ika value in history textbooks. It is qualitative research using critical discourse analysis, particularly representative analysis model by Roger Fowler. Data sources in the research are the senior high school textbooks based on 2006 curriculum which can be downloaded at bse.kemdikbud.go.id. website. Method of collecting data is conducted by documentation technique. The validity of discourse analysis refers to Ibnu Hamad's opinion, namely holistic, historical situatedness, and theory. Next, analysis is conducted using critical discourse analysis by Fairclough namely description, interpretation and explanation. The result of research shows that Bhineka Tunggal Ika is represented in various themes such as assimilation/acculturation/ syncretism, differences/diversity/plurality/complexity/ multicultural, distinction/discrimination and unity. Bhineka Tunggal Ika should be understand as both a result and continuous process.
\end{abstract}

Keywords: representation, Bhineka Tunggal Ika, history textbooks

\begin{abstract}
ABSTRAK
Buku teks merupakan salah satu sumber belajar yang digunakan dalam pembelajaran sejarah di sekolah. Pembelajaran sejarah berfungsi untuk melestarikan memori kolektif dan nilai-nilai yang dianggap penting, salah satunya Bhineka Tunggal Ika. Penelitian ini bertujuan untuk untuk mengungkap penggambaran dan representasi nilai Bhineka Tunggal Ika dalam buku teks sejarah. Penelitian ini merupakan penelitian kualitatif dengan menggunakan metode analisis wacana kritis, terutama analisis representasi model Roger Fowler. Sumber data pada penelitian ini adalah buku teks sejarah SMA berdasarkan kurikulum 2006 yang dapat diunduh pada laman bse.kemdikbud.go.id. Pengumpulan data dilakukan dengan teknik dokumentasi.Validitas analisis wacana mengacu pada pendapat Ibnu Hamad, yaitu holistic, historical situatedness, dan teori.Selanjutnya analisis dilakukan dengan menggunakan model analisis wacana kritis Fairclough yaitu deskripsi, interpretasi, dan eksplanasi. Hasil penelitian menunjukkan bahwa Bhineka Tunggal Ika direpresentasikan dalam berbagai tema seperti pembauran/akulturasi/sinkretisme, perbedaan/ keragaman/ pluralitas/ kemajemukan/ multikultural, pembedaan/diskriminasi serta persatuan dan kesatuan. Bhineka Tunggal Ika perlu dipahami sebagai hasil maupun proses yang terus berlanjut.
\end{abstract}

Kata-kata kunci: representasi, Bhineka Yunggal Ika, buku teks sejarah

\section{PENDAHULUAN}

Kebhinekaan merupakan bagian dari kehidupan masyarakat Indonesia. Ia tidak terjadi secara tiba-tiba namun melalui proses historis yang panjang. Jauh sebelum masyarakat Barat mendengungkan wacana multikulturalisme, masyarakat Indonesia telah hidup dengan kebhinekaan yang sangat kaya yang meliputi suku bangsa, bahasa, adat istiadat, agama, dan sebagainya.

Kebhinekaan tersebut merupakan anugerah bagi masyarakat Indonesia. Namun jika tidak dapat disikapi dengan baik, maka kebhinekaan justru menjadi 
Wacana Bhineka Tunggal Ika ... - Indah Wahyu Puji Utami \& Aditya Nugroho Widiadi

musibah. Pasca reformasi 1998 terjadi berbagai konflik akibat perbedaan suku bangsa atau agama di Indonesia seperti konflik Sampang, Poso, maupun konflik Syiah di Madura. Peristiwa-peristiwa tersebut tidak perlu terjadi jika kita mau belajar dari sejarah bangsa Indonesia. Para founding fathers Indonesia terdiri dari berbagai latar belakang suku bangsa, agama bahkan ideologi, namun mereka berhasil menyingkirkan egoisme pribadi atau kelompoknya demi kepentingan bangsa dan negara. Tidak mengherankan pula jika mereka memasukkan semboyan Bhineka Tunggal Ika dalam lambang negara.

Pemahaman dan pemaknaan masyarakat terhadap kebhinekaan tentu saja tidak terjadi secara tiba-tiba namun didapat dari proses belajar, salah satunya belajar sejarah. Buku teks merupakan salah satu sumber belajar sejarah yang penting di sekolah. Buku teks sejarah menyajikan kisah sejarah yang merupakan rekonstruksi dari peristiwa sejarah.

Pusat Perbukuan (2006:1) mengungkapkan buku teks adalah buku yang dijadikan pegangan siswa pada jenjang tertentu sebagai media pembelajaran (instruksional), berkaitan dengan bidang studi tertentu. Buku teks merupakan bu$\mathrm{ku}$ standar yang disusun oleh pakar dalam bidangnya. Buku teks pelajaran untuk setiap mata pelajaran yang digunakan pada satuan pendidikan dasar dan menengah dipilih dari buku-buku teks pelajaran yang telah ditetapkan oleh Menteri Pendidikan Nasional berdasarkan rekomendasi penilaian kelayakan dari Badan Standar Nasional Pendidikan (BSNP).

Muslich (2010:52) menyebutkan bu$\mathrm{ku}$ teks memiliki ciri-ciri yang berbeda dengan buku pendidikan lainnya baik dari segi isi, tata letak, maupun fungsinya. Ia menguraikan bahwa,

Dilihat dari segi isinya, buku teks merupakan buku yang berisi uraian bahan ajar bidang tertentu, untuk jenjang pen- didikan tertentu, dan pada tahun ajaran tertentu pula. Dilihat dari segi tata letaknya, buku teks merupakan sajian bahan ajar yang mempertimbangkan faktor (1) tujuan pembelajaran; (2) kurikulum dan struktur program pendidikan; (3) tingkat perkembangan siswa sasaran; (4) kondisi dan fasilitas sekolah; dan (5) kondisi guru pemakai. Dilihat dari segi fungsinya, selain mempunyai fungsi umum sebagai sosok buku, buku teks juga mempunyai fungsi sebagai (1) sarana pengembang bahan dan program dalam kurikulum pendidikan; (2) sarana pemelancar tugas akademik guru; (3) sarana pemelancar ketercapaian tujuan pembelajaran; dan (4) sarana pemelancar efisiensi dan efektifitas kegitan pembelajaran.

Menurut Helius Sjamsuddin (1998:103) kedudukan, fungsi dan peranan buku teks sejarah amat strategis karena menyangkut pembentukan aspek-aspek kognitif (intelektual) dan afektif (apresiasi, nilai-nilai) semua peserta didik dari setiap jenjang pendidikan. Sejarah nasional khususnya dianggap mempunyai nilai didaktif-edukatif bagi pembentukan jati diri bangsa dan pemersatu berdasarkan atas pengalaman kolektif bernegara dan berbangsa. Lebih lanjut ia menuliskan beberapa hal yang perlu diperhatikan oleh penyusun buku teks sejarah, yaitu (1) substansi faktualnya harus benar-benar dapat dipertanggungjawabkan secara akademis dan sedapat mungkin menggunakan sumber primer; (2) penafsiran atau penjelasannya harus logis, sistematis, serta memperhatikan visi atau kebijakan pendidikan dan atau politik yang berlaku secara nasional; (3) penyajian dan retorikanya harus sesuai jenjang usia siswa menurut teori psikologi perkembangan yang umum dikenal; (4) pengenalan konsep-konsep sejarah perlu menggunakan pendekatan "spiral", dimulai dari konsep sederhana menuju konsep yang lebih kompleks; (5) secara teknis 
konseptual buku teks harus mengikuti Garis-garis Besar Program Pengajaran (GBPP) menurut kurikulum yang berla$\mathrm{ku}$; dan (6) ada kelengkapan ilustrasi, gambar, foto, peta-peta sejarah dalam setting dan lay out yang inovatif dan atraktif (1998:104-105).

Menurut Wawan Darmawan (2010:100) "the history lesson text book as a historiography work for educational purpose does not ignore the historiographycal rules of history science". Idealnya, harus ada sinkronisasi antara sejarah akademis dengan sejarah untuk kepentingan pendidikan di dalam buku teks. Namun, hal ini tidak mudah karena adanya perbedaan tujuan dalam penulisan historiografinya. Sejarah akademis terutama bertujuan untuk mencari kebenaran ilmiah melalui metode sejarah, sementara itu sejarah untuk kepentingan pendidikan diarahkan untuk penanaman nilai dan pelestarian memori kolektif. Hal senada diungkapkan oleh Agus Mulyana (2011:10) bahwa kepentingan penanaman nilai atau ideologi dan kepentingan kajian kritis dalam buku teks seharusnya dapat dipadukan. Ideologi atau nilai-nilai dapat tertanam dalam diri siswa ketika membaca buku teks pelajaran sejarah secara kritis, bukan penanaman ideologi atau nilai-nilai yang bersifat indoktrinasi. Dengan demikian buku teks dapat dipandang sebagai wacana yang merepresentasikan nilai-nilai dan ideologi tertentu.

Wacana menampilkan nilai-nilai dan ideologi dengan cara tertentu sehingga dapat mengiring pemahaman dan pemaknaan pembacanya. Wacana tidak selalu menampilkan peristiwa secara apa adanya, namun ia adalah konstruksi dari realitas. Dalam hal ini subyektivitas dan kepentingan pembuat wacana turut berperan dalam konstruksi realitas. Ketidakpahaman peserta didik terhadap nilainilai yang hendak dilestarikan melalui pembelajaran sejarah bisa terjadi karena adanya representasi atau misrepresentasi dalam buku teks sejarah.

Wacana yang terdapat dalam buku teks sejarah tidak terjadi dalam ruang hampa. Ia selalu terikat dengan konteks yang lebih luas. Pilihan kata dalam studi wacana dipandang memiliki tujuan dan implikasi tertentu. Misalnya kata tewas dan meninggal mempunyai makna yang sama, namun kata meninggal dirasa lebih halus daripada kata tewas. Namun kata juga baru dapat dipahami dalam konteks kalimatnya. Kalimat yang merupakan bagian dari wacana juga harus dipahami dalam konteks yang lebih luas. Demikian pula buku teks yang memuat wacana sejarah juga harus dilihat dalam konteks yang lebih luas yaitu politik pendidikan. Hal ini karena buku teks disusun berdasarkan kurikulum yang merupakan produk kebijakan politik pendidikan pemerintah.

Penelitian tentang buku teks sejarah memang bukan hal baru. Niels Mulder (1997) melakukan kajian kritis terhadap buku-buku pelajaran sekolah di Indonesia. Penelitian mengenai buku teks sejarah pernah dilakukan oleh Murti Kusuma Wirasti (2001) yang mengkaji berbagai tema ideologi negara yang muncul dalam buku teks sejarah periode 1975-2001, salah satunya adalah tema nasionalisme/ persatuan dan kesatuan. Hyronimus Purwanta (2012) mengulas secara menarik wacana ideologi nasional yang terdapat dalam buku teks sejarah yang dikonstruksikan sebagai pengganti identitas lokal dan cenderung dipaksakan. Hasil penelitiannya didukung oleh Agus Mulyana (2013) yang mengulas secara menarik tema nasionalisme dan militerisme yang mendominasi penulisan bu$\mathrm{ku}$ teks sejarah di Indonesia. Wacana nasionalisme dianggap sangat dominan dalam buku teks sejarah terutama dalam narasi tentang pembentukan negara bangsa. Sementara wacana militerisme sangat dominan dalam narasi tentang per- 
Wacana Bhineka Tunggal Ika ... - Indah Wahyu Puji Utami \& Aditya Nugroho Widiadi

juangan dalam sejarah nasional Indonesia. Hasil yang tidak jauh berbeda juga diungkap oleh Purwanta (2013) yang mengemukakan bahwa ideologi militerisme sangat dominan dalam penulisan buku teks sejarah di Indonesia 1975-1994. Kajian mengenai wacana dalam buku teks sejarah juga pernah dilakukan oleh Indah Wahyu Puji Utami (2014) yang menunjukkan bahwa praktik wacana dalam buku teks sejarah sangat dipengaruhi oleh kebijakan politik pendidikan yang dilakukan oleh pemerintah.

Berbagai penelitian di atas merupakan analisis yang sangat menarik tentang wacana dalam buku teks sejarah, namun belum ada yang secara spesifik membahas mengenai wacana Bhineka Tunggal Ika yang merupakan semboyan negara Indonesia. Bhineka Tunggal Ika merupakan nilai yang sangat penting dalam kehidupan berbangsa dan bernegara di Indonesia.

Persoalan semboyan negara Bhineka Tunggal Ika mulai menjadi pembicaraan terbatas antara Muhammad Yamin, Bung Karno, I Gusti Bagus Sugriwa dalam sidang-sidang BPUPKI sekitar dua setengah bulan sebelum Proklamasi (Sekjen MPR RI, 2012:170). Semboyan tersebut secara resmi diatur dalam PP No. 66 tahun 1951 tentang lambang negara.

Semboyan Bhineka Tunggal Ika dapat ditelusuri dari Kitab Sutasoma karangan Mpu Tantular. Bhineka Tunggal Ika secara harfiah mengandung arti bhine$k a$ (beragam), tunggal (satu), dan ika (itu). Ungkapan ini sebenarnya menggambarkan keberagaman agama yang dianut oleh masyarakat Majapahit. Meskipun berbeda, namun penganut kedua agama tersebut dapat hidup berdampingan. Semboyan tersebut kemudian ditafsirkan lagi dan disesuaikan dengan konteks Indonesia. Penjelasan PP No. 66 tahun 1951 menyebutkan,

perkataan Bhinneka itu ialah gabungan dua perkataan: bhinna dan ika. Kalimat seluruhnya itu dapat disalin: berbeda- beda tetapi tetap satu jua. Pepatah ini dalam sekarang artinya, karena menggambarkan persatuan atau kesatuan Nusa dan Bangsa Indonesia, walaupun ke luar memperlihatkan perbedaan atau perlainan. Kalimat itu telah tua dan pernah dipakai oleh pujangga ternama Empu Tantular dalam arti: di antara pusparagam adalah kesatuan."

Menurut Agustin (2011:195) Bhineka Tunggal Ika merupakan gambaran dari kesatuan geopolitik dan geobudaya Indonesia yang artinya terdapat keberagaman agama, ide, ideologi, suku bangsa, dan bahasa.

Bhineka Tunggal Ika merupakan salah satu nilai yang direpresentasikan dalam buku teks sejarah. Representasi nilai tersebut dapat dilihat dari kata dan kalimat yang digunakan dalam buku teks. Guna memahami representasi maka harus dilihat pula dalam konteks politik pendidikan. Dengan demikian wacana tidak hanya dilihat dalam level mikro saja tapi dikaitkan dengan level makro sebagai konteksnya.

Representasi merupakan sebuah konsep dalam komunikasi, terutama dalam kajian wacana. Wacana dalam kajian ini mengacu pada pendapat Rebecca Rogers (2005:370) yang mengungkapkan

\begin{abstract}
...discourse has been defined as language use as social practice. That is, discourse moves back and forth between reflecting and constructing the social world. Seen in this way, language can not be considered neutral, because it is caught up in political, social, racial, economic, religious, and cultural formations.
\end{abstract}

Taufik Abdullah (2005:xviii) mengungkapkan bahwa sejarah sesungguhnya dapat dianggap sebagai suatu sistem wacana, discourse, yang ingin mengatakan "sesuatu tentang sesuatu". Wacana sejarah terikat oleh konteksnya, terutama konteks waktu yang merupakan salah satu ciri khas dari studi sejarah. 
Wacana tidak dipahami sebagai sesuatu yang netral sehingga perlu dilihat secara kritis.

Wacana memiliki potensi untuk menggiring pandangan dan pemikiran pembacanya sesuai dengan keinginan pembuat teks. Eriyanto (2001:74-75) menyebutkan bahwa,

Wacana membatasi bidang pandangan kita, mengeluarkan sesuatu yang berbeda dalam batas-batas yang telah ditentukan. Ketika aturan dari wacana dibentuk, pernyataan kemudian disesuaikan dengan garis yang telah ditentukan. ... Objek bisa jadi tidak berubah, tetapi struktur diskusrif yang dibuat membuat objek menjadi berubah.

Wacana dapat membatasi pandangan kita karena ia merepersentasikan suatu ide, konsep, gagasan, orang atau kelompok dengan cara tertentu. Istilah representasi merujuk pada bagaimana seseorang, kelompok, konsep atau gagasan ditampilkan dalam teks atau wacana. Eriyanto (2001) mengungkapkan bahwa teks tidak selalu sesuai dengan peristiwa karena ia hanya representasi penulis terhadap peristiwa dan oleh karenanya tidak pernah netral. Dalam kajian sejarah, historiografi juga tidak dipandang sebagai masa lalu itu sendiri melainkan konstruksi sejarawan terhadap peristiwa yang terjadi di masa lalu berdasarkan sumber-sumber sejarah. Sejarawan juga melihat dan merekonstruksi peristiwa sejarah dari perspektif tertentu dan dipengaruhi oleh subyektivitasnya sehingga ia juga tidak netral.

Terkait dengan persoalan representasi dalam wacana, Fiske (dalam Eriyanto, 2001) mengungkapkan bahwa saat menampilkan obyek, peristiwa, gagasan, kelompok, atau seseorang ada tiga proses yang dihadapi penulis, yaitu 1) bagaimana peristiwa dikonstruksi sebagai realitas oleh penulis, 2) bagaimana realitas itu digambarkan, dan 3) bagaimana peristiwa -peristiwa itu diorganisir ke dalam konvensi-konvensi yang diterima secara ideologis. Namun sebelumnya setiap penulis pasti dihadapkan pada pemilihan fakta dalam suatu peristiwa yang akan dituliskan. Proses pemilihan fakta ini menurut Eriyanto (2010:117-118) menimbulkan akibat yang sangat jauh karena begitu fakta didefinisikan di sana selalu terjadi proses pemilihan, penonjolan, atau penghilangan bagian tertentu dari realitas dalam praktik wacana.

Buku teks sejarah merupakan bagian dari praktik wacana. Historiografi dalam buku teks bukanlah cerminan dari peristiwa dari masa lalu, namun ia hanyalah representasi dari realitas yang ditampilkan oleh penulisnya dalam bentuk wacana. Ia mengandung nilai-nilai atau ideologi tertentu. Hal ini karena salah satu tujuan pembelajaran sejarah adalah untuk melestarikan nilai-nilai yang dianggap penting.

\section{METODE PENELITIAN}

Penelitian ini merupakan penelitian kualitatif dengan menggunakan metode analisis wacana kritis, terutama analisis representasi Roger Fowler, dengan empat buku teks sejarah sebagai subyeknya. Wacana merupakan bahasa yang digunakan dalam praktik sosial. Fowler (dalam Eriyanto, 2001:137) mengungkapkan bahwa bahasa pada dasarnya bersifat membatasi, kita diajak berpikir untuk memahami seperti itu, bukan yang lain. Pemilihan kata sangat berpengaruh pada cara kita memahami dan memaknai peristiwa. Kosa kata tertentu akan dihubungkan dengan realitas tertentu. Katakata selanjutnya dirangkai dalam kalimat dan menjadi wacana yang merepresentasikan obyek, peristiwa, gagasan, kelompok, atau seseorang. Representasi tersebut juga akan dikaitkan dengan konteks yang lebih luas yaitu politik pendidikan. 
Buku teks yang akan dikaji dalam penelitian ini adalah BSE Sejarah Kelas XI IPS. Pemilihan buku teks tersebut karena kompetensi dasar dan standar kompetensi pada kelas tersebut membahas tentang persentuhan manusia dan budaya nusantara dengan manusia maupun budaya asing. Keduanya kemudian saling mempengaruhi, bahkan menghasilkan akulturasi budaya yang memperkaya budaya yang telah ada sebelumnya. Dengan demikian sebenarnya keberagaman merupakan bagian dari sejarah Indonesia. Adapun BSE Sejarah Kelas XI IPS adalah Sejarah (XI IPS) yang ditulis oleh Tarunasena.

Pengumpulan data dilakukan dengan cara dokumentasi. Peneliti dalam hal ini tidak sekedar mencatat isi dokumen tapi juga maknanya yang tersirat. Konsep dan nilai Bhineka Tunggal Ika dikonstruksikan dan direpresentasikan dalam teks melalui kata dan kalimat. Selanjtnya data yang telah terkumpul dianalisis mengikuti teknik analisis wacana kritis yang dikembangkan oleh Norman Fairclough (1998) yang terdiri dari deskripsi, interpretasi, dan eksplanasi.

\section{HASIL DAN PEMBAHASAN}

Beberapa tema yang direpresentasikan dalam teks terkait dengan Bhineka Tunggal Ika antara lain pembauran, akulturasi, sinkretisme, keragaman, pembedaan/diskriminasi, persatuan, kesatuan, dan nasionalisme. Tema-tema tersebut muncul dalam berbagai subbab di buku teks. Tema-tema tentang pembauran, akulturasi, sinkretisme dan keragaman lebih banyak muncul pada subbabsubbab awal buku teks ini yang membahas sejarah masuknya pengaruh Hindu Budha hingga Islam ke nusantara yang memperkaya keragaman atau kebhinekaan yang telah ada sebelumnya.
Kebhinekaan perlu dipahami tidak hanya sebagai hasil namun juga proses yang panjang dari interaksi antara unsurunsur lokal dengan asing yang masuk terutama melalui jalur perdagangan. Pelayaran dan perdagangan di masa kuno perlu dipahami sebagai bentuk globalisasi kuno. Globalisasi bukanlah fenomena baru dalam sejarah manusia. Anthony Giddens (dalam Chaubet, 2015) menyebut globalisasi sebagai perluasan dan intensifikasi relasi-relasi sosial pada tingkatan dunia.

Pelayaran dan perdagangan pada masa kuno merupakan bentuk awal globalisasi meskipun jangkauan dan jaringan yang dibangun masih terbatas. Chaubet (2015) menyebut globalisasi sebagai hubungan-hubungan dan sirkulasi-sirkulasi antara sejumlah wilayah geografis yang kurang lebih berjauhan sebagai proses sejarah yang sangat kuno dan silih berganti. Menurutnya gelombang globalisasi kuno berlangsung sejak zaman perunggu hingga abad XVII. Pada periode itu arus pertukaran dan peminjaman budaya menjadi umum.

Para pedagang berperan penting sebagai agen dalam arus globalisasi kuno. Menurut Chaubet (2015) perluasan geografis jalur-jalur perdagangan berimbas pada tumbuhnya kota-kota terutama kota pelabuhan yang kosmopolit seperti Malaka yang pada awal abad XVI dihuni oleh 100.000 hingga 200.000 penduduk dengan 85 bahasa yang berbeda. Globalisasi memilki peranan yang besar dalam menyuburkan keragaman masyarakat terutama di daerah pesisir. Para pedagang baik lokal maupun asing yang melakukan diaspora transnasional memiliki peran penting dalam arus pertukaran dan peminjaman budaya.

Jalur perdagangan juga berperan dalam sirkulasi dan perluasan agama. Teks-teks yang terdapat dalam Bab I hingga $\mathrm{V}$ menggungkapkan tentang hal ini. Agama-agama baru masuk dan berkem- 
bang ke nusantara melalui jalur perdagangan yang menghubungkan Cina dan India. Letak geografis kepualaun nusantara yang strategis memungkinkan terjadinya hal tersebut. Cahubet (2015) menyebutkan bahwa di Kepulauan Indonesia antara abad VII - XV terbentuk komunitas budaya yang didukung oleh para pedagang yang juga menyebarkan agama dan budaya.

Masyarakat nusantara dalam buku teks direpresentasikan sebagai orangorang yang tidak menerima begitu saja pengaruh asing tersebut. Masyarakat lokal di nusantara digambarkan memiliki local genius sehingga melahirkan berbagai bentuk pembauran, akulturasi bahkan sinkretisme. Local genius menurut Wales (dalam Magetsari, 1986) ialah kemampuan kebudayaan setempat dalam menghadapi pengaruh kebudayaan asing pada waktu kedua kebudayaan itu berhubungan.

Berbagai bentuk akulturasi kebudayaan yang tumbuh sebagai hasil interaksi dan pembauran antara kebudayaan lokal dengan kebudayaan asing ditampilkan dalam buku teks. Sebagai contoh, dalam narasi mengenai masa klasik (Hindu Budha) penulis menggambarkan berbagai bentuk akulturasi salah satunya Candi Borobudur. Candi bercorak Budha yang ditandai dengan bentuk stupa dan relief-relief cerita Budha, namun candi tersebut juga memiliki bentuk seperti punden berundak yang merupakan keberlanjutan dari tradisi megalitik. Soediman (1986) menganggap bentuk stupa Borobudur yang menyerupai punden berundak sebagai local genius.

Percampuran atau akulturasi kebudayaan yang diwarnai oleh local genius masyarakat nusantara membuat kebudayaan yang ada di kepulauan nusantara makin berkembang. Sjafe'i (1986) menyebut bahwa akulturasi terjadi karena adanya hubungan antara dua kebudayaan masyarakat atau bangsa. Hub- ungan tersebut juga mengakibatkan terjadinya sebaran (difusi) kebudayaan. Anasir-anasir kebudayaan yang datang dapat diterima dan dapat disesuaikan dengan pola kebudayaan yang menerima. Ada dua kemungkinan yang dapat terjadi dalam proses tersebut yaitu perombakan atau penyesuaian kebudayaan. Lebih lanjut Sjafe'i (1986) menyebutkan bahwa proses percampuran kebudayaan tersebut terjadi secara tidak disadari.

Akulturasi kebudayaan bahkan sinkretisme hanya dimungkinkan terjadi dalam masyarakat yang terbuka dan toleran. Pertumbuhan masyarakat kota perdagangan di kawasan pesisir yang disinggahi banyak pedagang asing dengan sikap terbuka dan toleran pada akhirnya melahirkan bentuk-bentuk kebudayaan baru yang berbeda dengan aslinya. Toleransi menurut Rohidin (2015) merupakan sikap saling menghormati dan menghargai aktivitas yang dilakukan orang lain. Toleransi ini memungkinkan akan adanya kesadaran masing-masing individu untuk menghargai dan menghormati pendapat serta aktivitas yang dilakukan oleh kelompok masyarakat lain yang berbeda.

Bhineka Tunggal Ika juga direpresentasikan dalam tema keberagaman atau pluralitas. Magnis-Suseno (2015) menyebut bahwa pluralisme adalah hakiki bagi Indonesia. Baginya, hanya seorang pluralis yang bisa toleran. Toleransi menurutnya adalah penerimaan gembira terhadap kenyataan bahwa di sekitar kita hidup orang-orang dengan kepercayaankepercayaan dan agama-agama yang berbeda-beda. Sementara itu Rohidin (2015) memahami pluralisme sebagai pandangan yang menghargai kemajemukan serta menghormati pihak lain, membuka diri terhadap warna-warni keyakinan, kerelaan untuk berbagi, serta keterbukaan untuk saling belajar. Dengan demikian toleransi dan pluralisme bukankan ba- 
Wacana Bhineka Tunggal Ika ... - Indah Wahyu Puji Utami \& Aditya Nugroho Widiadi

rang jadi yang statis melainkan perlu dipahami sebagai proses yang dinamis.

Pluralisme seringkali dikaitkan dengan multikultural. Multikulural merupakan salah satu representasi kebhinekaan yang muncul dalam buku teks. Multikultural mengacu pada kenyataan adanya keragaman, sementara pluralitas menggambarkan keanekaragaman budaya sebagaimana adanya dalam suatu kelompok masyarakat (Molan, 2015).

Keragaman muncul dalam semua bab yang dianalisis. Keragaman lebih banyak direpresentasikan secara positif meskipun di beberapa bagian digambarkan bahwa perbedaan atau keragaman bisa memicu konflik. Keragaman budaya dan agama diakui oleh masyarakat nusantara. Keragaman yang lahir sebagai hasil dari proses sejarah yang panjang sejak masa kuno dan terus berlanjut hingga sekarang.

Keragaman adalah hal agama misalnya dapat tumbuh dan berkembang pada masa Hindu Budha. Dalam narasinya tentang pengaruh kebudayaan Hindu Budha di Indonesia, penulis teks merepresentasikan masyarakat nusantara dapat menerima keragaman agama dan budaya. Sebagai contoh, masyarakat pada masa itu digambarkan ada yang masih mempertahankan agama dan kepercayaan asli, ada pula yang menganut agama Hindu maupun Budha. Agama Hindu dan Budha yang berkembang di nusanatra juga memiliki corak yang khas dan berbeda dengan di negeri asalnya. Begitu pula yang terjadi dengan agama Islam yang masuk dan berkembang di Indonesia. Dalam narasinya tentang masuknya Islam penulis buku teks menggambarkan bahwa Islam masih menghargai kepercayaan masyarakat sebelumnya dan mengakomodasinya dalam dakwah. Dengan demikian maka memperkaya keragaman agama dan budaya di nusantara.
Mas'udi (2015) menyebutkan bahwa Islam yang masuk ke nusantara diaktualisasikan tanpa mengharamkan identitas kebangsaan dan kesukuannya. Saat berdakwah, para wali mensenyawakan Islam sebagai esensi dengan kenusantaraan dengan warisan budaya dan tradisinya atau dengan kata lain Islam dipribumikan. Said Agil Siroj (2015) menyebutkan bahwa para pendakwah islam di nusantara sejak dulu tidak serta merta melakukan pembumihangusan terhadap kearifan-kearifan lokal yang sudah lama berserakan di nusantara. Warisan tradisi lokal yang ada di bumi nusantara tidak dihancurkan dan diganti dengan simbolsimbol keislaman yang literalis. Para ulama nusantara juga dikenal sebagai cendekiawan yang berwawasan luas, penulis yang kreatif dan produktif, serta terlibat dalam berbagai aspek kehidupan sosial, politik, budaya, dan spiritualitas. Sebagai contoh, dalam buku teks penulis menggambarkan bahwa penyebaran Islam di Jawa dilakukan melalui jalur kesenian dengan memadukan anasir lokal dengan Islam seperti yang tampak dalam kesenian wayang yang digubah oleh Sunan Kalijaga agar sesuai dengan nilai-nilai Islam. Cerita-cerita Mahabarata dan Ramayana yang berasal dari masa Hindu Budha tetap dipertahankan dan disesuaikan dengan nilai-nilai Islam. Begitu pula dengan Sunan Derajat, Sunan Muria, dan Sunan Giri yang tidak hanya berdakwah dengan cara ceramah atau melalui kesenian, namun juga aktif memberdayakan masyarakat melalui kegiatankegiatan sosial. Dengan demikian, nilainilai Islam universal dan inklusif dapat diterima dengan damai oleh masyarakat.

Keragaman juga muncul dalam narasi tentang kedatangan bangsa Barat hingga kolonialisme yang mereka lakukan di nusantara. Chaubet (2015) menyebutkan bahwa hubungan-hubungan awal antara Asia dan Eropa terjadi pada abad XV yang ditandai dengan bangkit- 
nya kekuatan maritim Portugis secara perlahan. Portugis menaklukkan Malaka pada 1511 yang memungkinkan mereka mengontrol sejumlah perdagangan antara India, Indonesia dan Tiongkok. Kedatangan Portugis ke kepulauan nusantara segera disusul dengan bangsa-bangsa Eropa lainnya, termasuk Belanda.

Bangsa-bangsa Eropa yang datang ke nusantara dikonstruksikan secara negatif dalam buku teks. Mereka digambarkan sebagai bangsa yang serakah dan ingin menjajah serta memecah belah masyarakat nusantara. Jika pada narasi bab-bab sebelumnya banyak dibahas tentang perbedaan atau keberagaman maka pada narasi yang terkait dengan bangsa Barat di nusantara tema yang menonjol adalah pembedaan atau diskriminasi.

Perbedaan direpresentasikan sebagai hal yang wajar dalam masyarakat nusantara sementara pembedaan atau diskriminasi adalah situasi yang dipaksakan oleh penjajah (Belanda). Diskriminasi tersebut menempatkan penduduk lokal sebagai golongan masyarakat yang paling rendah, sementara orang-orang Eropa berada di golongan paling atas dan orang Timur Asing berada di golongan menengah. Perbedaan merupakan konsep yang negatif tentang keberagaman. Jika pluralitas ataupun multikultiral mengakui perbedaan dalam sudut pandang bahwa masing-masing kebudayaan memiliki kedudukan yang sama, maka diskriminasi atau pembedaan adalah kebalikannya.

Bhineka Tunggal Ika selain direpresentasikan dalam perbedaan maupun pembedaan, juga ditampilkan dalam tema persatuan dan kesatuan. Kesadaran akan perlunya integrasi antarwilayah di nusantara atau imajinasi atas wilayah yang lebih luas sudah ada sejak masa Hindu Budha. Beberapa kerajaan direpresentasikan memiliki cita-cita persatuan seperti Majapahit. Tentu saja persatuan pada masa tersebut tidak sama dengan konteks masa kini.

Tema persatuan makin dominan dalam narasi tentang pergerakan nasional. Para tokoh pergerakan digambarkan memilki kesadaran akan pentingnya persatuan dan kesatuan untuk mewujudkan Indonesia Merdeka. Hal ini merupakan nilai positif yang perlu ditanamkan ke bangsa Indonesia saat ini. Anies Baswedan (2015) menyebutkan bahwa para pendiri republik sadar bahwa bangsa di nusantara ini amat bhineka. Kebhinekaan bukanlah barang baru. Kebhinekaan di nusantara baginya adalah fakta, bukan masalah. Lebih lanjut ia menyebutkan bahwa tenun kebangsaan Indonesia dirajut dari kebhinekaan suku, adat, agama, keyakinan, bahasa, dan geografis yang sangat unik. Perajutan tenun kebangsaan merupakan proses yang terus berlanjut dengan dialog dan tawarmenawar yang amat dinamis pada setiap era.

Merajut tenun kebangsaan menjadi sebuah persatuan yang kuat adalah tema yang dominan dalam narasi pergerakan nasional di buku teks. Pendidikan Barat yang diterima oleh masyarakat Indonesia menumbuhkan kesadaran bahwa selama ini mereka diperlakukan tidak adil. Perjuangan yang bersifat kedaerahan pun digantikan dengan perjuangan nasional yang puncaknya menurut penulis buku teks ada dalam peristiwa Kongres Pemuda II yang kini diperingati sebagai Sumpah Pemuda.

Penulis buku teks menggambarkan bahwa organisasi-organisasi kepemudaan yang berbasis kedaerahan berkumpul dan merumuskan ikrar yang menjadi sumpah pemuda. Ikrar itu menunjukkan kuatnya keinginan untuk bersatu. Menurut Baswedan (2015) para pemuda mahfum bahwa mereka masih tersekat oleh kebhinekaan yang perlu disatukan dalam basis kebangsaan. Ada kesadaran baru bahwa suku-suku bangsa di nusantara ini 
Wacana Bhineka Tunggal Ika ... - Indah Wahyu Puji Utami \& Aditya Nugroho Widiadi

akan meraih masa depan yang gemilang jika mereka memiliki persatuan dan kebersamaan.

Ma'arif (2015) menyebutkan bahwa sejak era pergerakan nasional para tokoh yang berlainan agama saling bahumembahu bekerja sama demi kemerdekaan Indonesia. Menurutnya, fakta sejarah tersebut perlu sering dikatakan agar kekuatan integrasi nasional semakin menguat di tengah-tengah pluralisme agama dan subkultur yang beragam.

Keberagaman ideologi dalam pergerakan nasional juga direpresentasikan dalam teks. Namun keberagaman tersebut dipandang sebagai sebuah kewajaran akibat beragamnya ideologiidelogi besar yang masuk ke Indonesia melalui sistem pendidikan Barat seperti nasionalisme, sosialisme, komunisme dan sebagainya. Keberagaman itu dipersatukan oleh semangat dan cita-cita Indonesia Merdeka.

Mata pelajaran sejarah yang diajarkan di sekolah memiliki peranan strategis dalam menumbuhkembangkan kesadaran akan pentingnya bhineka tunggal ika sebagai hasil dan proses yang terus berlanjut. Oleh karenanya dalam KTSP disebutkan bahwa kurikulum dikembangkan dengan memperhatikan kepentingan nasional dan kepentingan daerah. Keduanya harus saling mengisi dan memberdayakan sejalan dengan motto Bhineka Tunggal Ika dalam kerangka NKRI. Materi sejarah dalam KTSP "menanamkan kesadaran persatuan dan solidaritas untuk menjadi perekat bangsa dalam menghadapi ancaman disintegrasi bangsa."

\section{SIMPULAN}

Bhineka Tunggal Ika merupakan semboyan negara Indonesia. Kata bhineka ditafsirkan sebagai keberagaman sementara kata ika ditafsirkan sebagai kesatuan sehingga secara sederhana bhineka tunggal ika diartikan sebagai keberagaman dalam persatuan. Bhineka tunggal ika direpresentasikan melalui berbagai tema dalam buku teks, antara lain, keberagaman / kemajemukan / pluralitas / multikultural yang merupakan hasil dari proses interaksi yang melahirkan akulturasi kebudayaan. Semua hal ini dimungkinkan karena adanya sikap keterbukaan dan toleransi serta local genius masyarakat lokal di nusantara.

Letak geografis kepulauan nusantara bagi pelayaran dan perdagangan sejak masa kuno membuat globalisasi tidak terelakkan. Dalam proses globalisasi itulah terjadi interaksi yang melahirkan difusi dan akulturasi kebudayaan.

Bhineka tunggal ika juga direpresentasikan dalam tema persatuan dan kesatuan. Kesadaran akan pentingnya persatuan dan kesatuan terutama muncul dalam narasi tentang pergerakan nasional. Kebhinekaan disadari sebagai bagian fakta sejarah dan persatuan dipahami sebagai proses yang terus berlanjut.

Bhineka tunggal ika tidak hanya direpresentasikan sebagai hasil atau produk budaya, melainkan sebagai proses. Pemahaman tentang proses yang dinamis inilah yang perlu disampaikan dan ditanamkan di kalangan peserta didik. Indonesia bukan sekedar hasil dari sejarah yang panjang, melainkan proses menjadi yang akan terus berlanjut di masa kini maupun yang akan datang.

\section{DAFTAR PUSTAKA}

Abullah, T. 2005. "Kata Pengantar" dalam Sartono Kartodirjo. Sejak Indisch sampai Indonesia. Jakarta: Penerbit Buku Kompas.

Agustin, Sari Monik. 2011. "Bhinneka Tunggal Ika atau Bhineka Tunggal Ika (Sebuah Tinjauan Paradigma Klasik Ilmu Sosial dalam Keberagaman dan Persatuan di Indonesia)." Konferensi Nasional Komu- 
nikasi "Membumikan Komunikasi di Indonesia". Depok: Departemen Ilmu Komunikasi FISIP UI. 194-202.

Baswedan, A. 2015. Merawat Tenun Kebangsaan: Refleksi Ihwal Kepemimpinan, Demokrasi, dan Pendidikan. Jakarta: Serambi.

Chaubet, F. 2015. Globalisasi Budaya. Yogyakarta: Jalasutra.

Creswell, J.W. 2009. Research Design: Qualitative, Quantitative and Mixed Method Approaches. Los Angeles: Sage

Darmawan, W. 2010. "Historiography Analysis of History Text Book from Neerlandocentric to Scientific" dalam Historia: International Journal of History Education, Vol. XI, No. 2., 99-118

Darmiasti. 2002. "Penulisan Buku Pelajaran Sejarah Indonesia untuk Sekolah Menengah Atas tahun 1964 - 1984: Sejarah Demi Kekuasaan". Tesis. Tidak diterbitkan. Jakarta: Universitas Indonesia

Eriyanto. 2001. Analisis Wacana: Pengantar Analisis teks Media. Yogyakarta: LKiS.

Fairclough, N. 1998. Language and Power. London: Longman.

Hamad, I. 2012. Perkembangan Analisis Wacana dalam Ilmu Komunikasi. dalam http:// www/scribd.com/doc/45888147/DrIbnu-Hamad diakses 9 Maret 2012, pukul 17.30.

Hasan, S. H. 2008. "Pendidikan Sejarah Dalam Rangka Pengembangan Memori Kolektif dan Jati Diri Bangsa" dalam M. Nursam, Baskara T. Wardaya S.J., dan Asvi Warman Adam (Eds) Sejarah yang Memihak: Mengenang Sartono Kartodirjo. Yogyakarta: Ombak

Ma'arif, A.S. 2015. Islam dalam Bingkai Keindonesiaan dan Kemanusiaan: Sebuah Refleksi Sejarah. Bandung: Mizan

Magetsari, N. 1986. "Local Genius dalam Kehidupan Beragama" dalam Ayotrohaedi. Kepribadian Budaya Bangsa (Local Genius). Jakarta: Pustaka Jaya.

Magnis-Suseno, F. 2015. Kebangsaan, Demokrasi, Pluralisme: Bunga Rampai Etika Politik Aktual. Jakarta: Penerbit Buku Kompas.

Mas'udi, M.F. 2015. "Islam (di) Indonesia" dalam Abdullah Ubaid dan Mohammad Bakir. Nasionalisme dan Islam
Nusantara. Jakarta: Penerbit Buku Kompas.

Molan,, B. 2015. Multikulturalisme: Cerdas Membangun Hidup Bersama yang Stabil dan Dinamis. Jakarta: PT Indeks.

Mulder, N. 1997. Individu, Masyarakat dan Sejarah. Yogyakarta: Kanisius.

Mulyana, A. 2011. Historiografi Buku Teks Pelajaran Sejarah di Sekolah: Antara Kepentingan Kekuasaan dan Studi Kritis. dalam http://berita.upi.edu/2011/07/26/ historiografi-buku-teks-pelajaran-disekolah/ diakses 25 Agustus 2011, pukul 12.55.

Muslich, M. 2010. Textbook Writing: Dasar-dasar Pemahaman, Penulisan, dan Pemanfaatan Buku Teks. Yogyakarta: Ar Ruzz Media

PP No. 66 tahun 1951 tentang Lambang Negara

Rogers, R. 2005. "Critical Discourse Analysis in Education: A Review Literature" dalam Review of Educational Research, Vol. 75 No. 3., 365 - 416.

Rohidin. 2015. Konstruksi Baru Kebebasan Beragama: Menghadirkan Nilai Kemanusiaan yang Adil dan Beradab di Negara Hukum Indonesia. Yogyakarta: FH UII Press.

Sekjen MPR. 2012. Empat Pilar Kehidupan Berbangsa dan Bernegara. Jakarta: Sekretariat Jendral MPR RI.

Siroj, S.A. 2015. "Mendahulukan Cinta Tanah Air" dalam Abdullah Ubaid dan Mohammad Bakir. Nasionalisme dan Islam Nusantara. Jakarta: Penerbit Buku Kompas.

Sjafe'i, S. 1986. "Peranan Local Genius dalam Kebudayaan" dalam Ayotrohaedi. Kepribadian Budaya Bangsa (Local Genius). Jakarta: Pustaka Jaya.

Soediman.1986. "Local Genius dalam Kehidupan Beragama" dalam Ayotrohaedi. Kepribadian Budaya Bangsa (Local Genius). Jakarta: Pustaka Jaya.

Tosh, J. 2010. The Pursuit of History. London: Routledge

Utami, I.W.P. 2012. “Wacana Ideologi Negara dalam Buku Sekolah Elektronik (BSE) Sejarah Sekolah Menengah Atas (SMA)". Tesis. Tidak diterbitkan. Surakarta: Universitas Sebelas Maret. 
Wacana Bhineka Tunggal Ika ... - Indah Wahyu Puji Utami \& Aditya Nugroho Widiadi

Wirasti, M.K. 2001. “Wacana Ideologi Negara dalam Pendidikan: Analisis Wacana Kritis pada Buku-buku Teks Pendidikan untuk SD dan SLTP Tahun 19752001". Tesis. Tidak diterbitkan. Jakarta: Universitas Indonesia 